\title{
FIRE PREVENTION IN OTTOMAN AND HABSBURG BUILDING CODES FOR BOSNIA AND THEIR APPLICATION IN TRAVNIK
}

\author{
A. CAROLINE JAEGER-KLEIN ${ }^{1,2 *}$, B. AJLA BAJRAMOVIC ${ }^{2}$ C. LUKAS STAMPFER $^{1}$ \\ Institute of History of Art, Building Archaeology and Restoration \\ Technical University if Vienna (TU-Wien), Karlsplatz 13/251-1, 1040 Vienna, Austria \\ e-mail: jaeger-klein@tuwien.ac.at (*corresponding author), lukas.stampfer@tuwien.ac.at, \\ www.baugeschichte.tuwien.ac.at \\ ${ }^{2}$ Department of Art History \\ University of Vienna, Garnisongasse 13, Campus courtyard 9, 1090 Vienna, Austria \\ e-mail: ajla.bajramovic@univie.ac.at, http://ercbos.univie.ac.at
}

Keywords: Fireproof Material, Building Regulations, Modernization, Building by Plan, TypePlanning, Identity and Architecture

\begin{abstract}
The city of Travnik, located in central Bosnia, served as an administrative center of the Ottoman province between 1699 and 1851, with only short interruptions. In 1878, the Congress of Berlin awarded the Austro-Hungarian Monarchy rights of occupation for this Ottoman province. The following year, the new administration already faced its first big fire, which wiped out a major part of downtown Sarajevo. A new building code, which tried to minimize future hazard risks and was soon valid for all of Bosnia, was established in 1880.
\end{abstract}

In September 1903, two major fires hit Travnik. The Ottoman administrative building used by the new officials was already fire-improved, so it survived the fires without sustaining any serious damage. The same cannot be said for the traditional residential neighborhoods at the foot of Travnik castle, which burnt down to their foundations. The mosques in Travnik that were constructed mostly of wood were damaged severely. Austro-Hungarian administration officials identified the traditional way of building as a serious risk for all of Bosnia and tried to counterbalance by implementing the new regulations rigidly in their post-fire reconstruction program. They seem to have developed a more secure 'mosque building model type', which they implemented in the re-erection of the Lončarica, Zulići, Kahvica and Šumećka mosques. While rebuilding the Varoška and Lukačka mosques, the distinct 'official' style of Habsburg-Bosnia [1], a blend of various architectural elements associated with 'the Orient' that the literature tends to name 'pseudo-Moorish', was used. 


\section{INTRODUCTION}

Located in central Bosnia, Travnik is a charming but sleepy midsized town that, according to the Austro-Hungarian census of 1895, had a population of ca. 5,933 [2]. Travnik enjoys a favourable location on the Lašva River, situated along an important north-south trade, and served as administrative centre of the Ottoman province of Bosnia Herzegovina from 1699 to 1851, with short interruptions in 1827-28 and 1832-36. Ottoman viziers and the consuls of Austria and France left traces in Ivo Andrič's Nobel-prize-winning literature as well as several buildings. The viziers resided and carried out their official duties in a distinct type of building called konak, and were buried in various mausoleums, called türbe in Turkish. After the take-over of Ottoman-Bosnia by the Habsburg monarchy in 1878, Travnik maintained its role as the capital of one of the six districts (in German named Kreise) into which Bosnia and Herzegovina was divided under the former rulers. After the arrival of Austro-Hungarian officials in Travnik, several modern building complexes intended for military, social (health-care, education) and religious infrastructural use were fitted into its existing city-scape. However, the old administrative building, the historic konak, was kept as the main administration centre. In October 1893, the Lašva-Donji Vakuf-Jajce/Bugoino railroad project reached Travnik. Its completion meant that Travnik was better connected with nearby towns, but it was exactly this railway's construction that caused a disastrous fire in September 1903.

The Austro-Hungarian government's interesting response to this serious catastrophe, and the previously initiated efforts to implement modern fire-proof building structures according to Austrian standards, are the subject of the following paper. The ERC project titled "Islamic architecture and Orientalizing style in Habsburg Bosnia, 1878-1918" (PI: Maximilian Hartmuth, University of Vien-

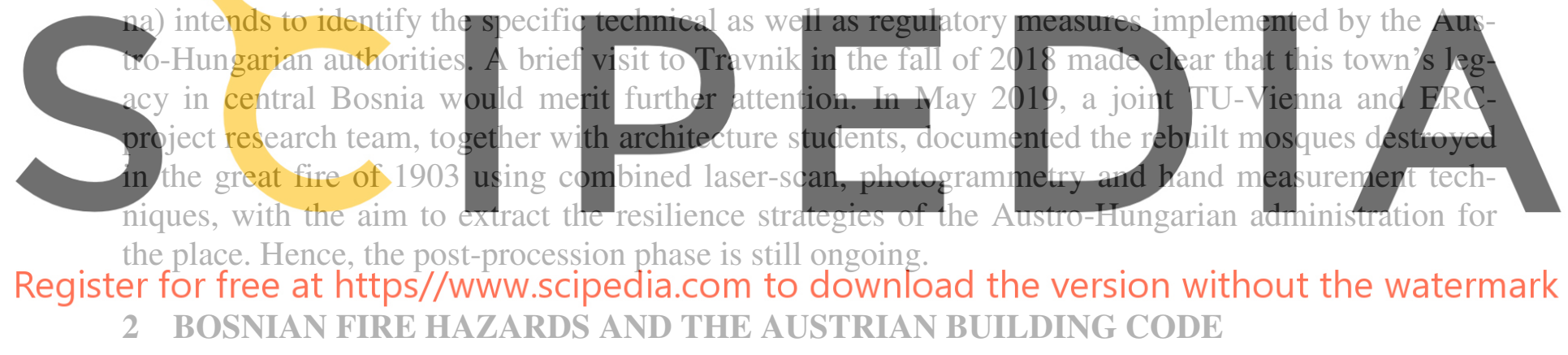

The Austro-Hungarian monarchy took over administration of Bosnia and the Hercegovina in the summer of 1878. For complicated matters of foreign and internal politics, "the chief architects of Austria's colonial policy were ... civil servants rather than legislators" [3]. The undoubted mastermind of that policy, Benjamin von Kallay, who governed the province from 1882 until 1903, stressed in an interview given to a British newspaper that "rational bureaucracy was the key to Bosnia's future ... Administration is our only politics" [4]. In accordance with that motto, officials rapidly implemented new urban planning and structural engineering rules and regulations as soon as they identified the major building security threat caused by Bosnia's traditional construction techniques. The capital of the Habsburg-Empire, Vienna, served as role model.

\subsection{A brief history of Austria's building regulations and its fire-care approach}

One crucial aspect of security that officials in urban areas have always faced has been to safeguard lives and property threatened by fires in densely populated neighborhoods, sometimes entire cities. Vienna, as the residence of Habsburg emperors since the $16^{\text {th }}$ century and of the Austro-Hungarian Empire since 1866, had overcome a series of city fires between the years 1252 and 1330 . Forty percent of its then majority wooden houses were destroyed. In order to avoid the repetition of such disasters, as early as 1534 the authorities implemented systemic regulations in order to counterbalance this specific threat [5]. In the 1720's, a new generation of fire-security regulations laid the grounds 
for a first Viennese Building Code. The great empress Maria-Theresa (1717-1780) again reformed the valid fire-regulations. Wooden shingles used for the roofs and timbered staircases were forbidden. Additionally, the profession of the chimneysweeper was created. For the construction business, those first regulations mandating the use of fireproof material meant a fundamental change. To accelerate that process, Maria-Theresa initiated the royal brick industries' foundation at Wienerberg for burnt brick production. Finally, her son, the great reformer Joseph II (1741-1790), launched further fire-regulations in 1782. They were structured into the following four chapters: 1) how to prevent fires, 2) how to deal with the risk of fire, 3) how to fight the fire and 4) what to do with fire-damaged sites and properties [6].

In 1829, the first consolidated Building Code for Vienna was proclaimed; it specifically addressed the administrative process related to building construction. The code regulated the obligations of the building parties before the site was opened, during the erection-phase and after the construction was finished. It also codified the maximum building-height, the minimum width of its corresponding streets and established an office of supervision for all building activities [7]. The Building Code of Vienna served as role model for all of Austria, a tradition that was continued in Bosnia and the Hercegovina. As soon as Sarajevo had its own building regulations, they were instituted for the entire province.

\subsection{The first big fire in Habsburg Bosnia and its consequences}

Already during their first year of administration, Austro-Hungarian officials were confronted with a fire catastrophe in Sarajes scribed the initial, more tammable goods and place ch had to be available De capital. In the night from August eighth to ninth of 187
district (čarsija) burnt down to its foumdations [8]. Prstc
easily applied preyentive measures concerning the storage
at critical sites such as the bazaar-area with the wooden shop
administration quickly worked but a building code for Sa 879, the entire
ojević has de-
of certain in-
g fire ladders,
s (ducans) [9].

lected other towns and market places in Bosnia and the Hercegovina. On 14 May 1880, this new

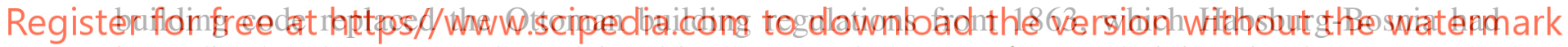
immediately taken over and proclaimed in German, the new regime's administrative language [10]. The Ottoman code already included directions similar to the Austro-Hungarian ones, but were insufficiently implemented and supervised. The Ottoman code's $\$ 24$ had already made fireproof chimneys obligatory. $\$ 25$ forbid building guesthouses in timber structures and $\$ 28$ required wooden roofcovers to be additionally protected by fire proofed material. For neighborhoods damaged by fire, the Ottoman building code prescribed wider streets and more open places than the traditionally constructed urban fabric would have provided $(\$ 12)$. The Austro-Hungarian administration added to the building code's 1880 version sanctions for not building in accordance with the licensed plan $(\S 14)$ and completely banned dead-end streets (Sackgassen) for new quarters, in addition to the mandated widening and straightening of the streets $(\$ 23)$.

Certainly, those regulations interfered fundamentally with the local town-planning tradition. Deadend streets were essential features of Ottoman-period residential neighborhoods (mahale in Bosnian) and their social control mechanisms. The fire-fighting rationale claimed for such regulations was the need for modern fire-fighting equipment and an adequate number of fire-fighting men to quickly reach the fire's heart and prevent its rapid expansion. Clearly, this was in contradiction to the traditional characteristics of Ottoman towns, where culture and climate ask for narrow, shadowed and hidden, and partially covered semi-public street space. However, as mentioned, the 1863 Ottoman building code already required the same measure as the Austro-Hungarian code from 1880. The ban of dead-end-streets was not a novelty of the new European regime, nor fire-proofed chimneys and roof-coverings. 
What was definitively new were regulations requiring the use of burnt brick in certain walldimensions or stone for public buildings and for residential- and commercial buildings. Existing roofs had to be covered with fireproof material within fifteen years. Based on Vienna's long-term experience - Vienna had avoided major urban fires like the one Sarajevo suffered in 1879 — buildings now had to be separated from each other with fire-proof walls (Feuermauern) surpassing the eves and space of the roofs. One stairway of fire-proof material (stone, for instance) had to run through the entire building up into the roof-space. The roof-space had to be divided by an iron door with a fireproof frame ( $\$ 40$, p. 259). Circulation corridors and the uppermost ceiling dividing the residential space from the roof-space had to be from fireproof material. It is not true that the regulations banned wooden or wooden-framework structures. They still could be erected if some space between the building and the neighboring structure was maintained. For structures with just a ground floor, wooden staircases still were allowed.

The 1880 Building Code's $\S 23$ regulated street (Gassen) width in four determined categories (Classen). To guarantee healthy conditions, in correlation to the width of the streets, the building-height of the neighboring residential houses was fixed by \$53. The amendment of 1893 [11] added a fifth class of streets in $\$ 23$ with a width of 15 meters. For the two widest street categories, permission for a third floor above the basement is given in $\$ 48$ if such a high building will not disturb harmony with the neighboring structures or the architectural effect within the street-view. No other health or security issues are criteria for the building code, while the argument of aesthetics is added. In general, the 1893 Building Code is more oriented toward city regulation measures, and deals less with fireproof materials and construction techniques. This may already show that the stricter supervision of an effi-


before the Austro-Hungarian occupation by noting that official administrative buildings like the ko-

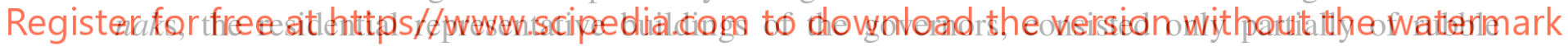
stone masonry and mostly of timber framework infilled with mudbrick [12]. Schmid described further that the chimney was often completely lacking and smoke had to exit through a roof hatch. A ceiling did not separate the roof space, and its coverings consisted of straw, rete or, like in central Bosnia, long wooden shingles.

However, many people avoided implementing the new building regulations. The governmentappointed building director, Edmund Stix, who was responsible for overseeing all building activities, reported as early as 1887 that modern building regulations nearly led to a standstill in all private building activities [13]. To counterbalance that, the provincial government on 18 May 1880 [14] released an order to exempt objects damaged or destroyed in the fire of 1879 from the housing-tax. If they were repaired or re-erected by November 1, 1884, the tax-relief was valid for 30 years. The exemption from the housing-tax was also valid for new structures or reconstructions outside the before mentioned scene-of fire, but with a more limited duration from five to twenty years. Schmid reports further that with such measures, and through the influence of building companies from other parts of the monarchy, finally the richer strata of Bosnian society could be convinced to equip their old buildings with modern and secure standards [15]. 


\section{AUSTRO-HUNGARIAN FIRE-PREVENTION FOR TRAVNIK AND THE GREAT FIRE OF 1903}

Travnik had - and still has - a well-preserved traditional building stock. After the 'era of viziers' ended there in 1851, few building activities took place in the town until the Austro-Hungarian district and county administrations were established. The Habsburg district administration (Kreisbehörde) finally settled in the existing Ottoman konak, referred to in the official plan documents as the 'great' konak (Großer Konak) because there also existed a smaller konak building. Obviously, the great konak needed some adaptations to fit the new administration's requirements. The Travnik Canton's district archive (Kantonalni arhiv Travnik) still holds an extant set of plans documenting this functional as well as technical adaptation process. Here, just the enhancement of the structure's fireproofing will be described as it helped to keep the great konak intact during the devastating fires of September 1903.

\subsection{Fireproof adaption of the existing Ottoman konak building}

Travnik became the capital of the 1580-founded Ottoman province of Bosnia during the second Bat-
tle of Vienna, which started in 1683 and lasted until 1699, when the Treaty of Karlowitz established
peace. As the Austrian Prince Eugene of Savoy occupied and demolished. Sarajevo in his 1697 as-
sault, the Sultan Mustafa II decided to move the vizier's seat to Travnik, which was safer and in a
better strategic position to defend the Ottoman Empire's western border. Between 1699 and 1851,77
viziers used the konak building as their home and operations base. It was erected on the city's western side in the early eigh needed to be modified bsburg administration


Register for free at https//www.scipedia.com to download the version without the watermark


Figure 1: Left: Reconstruction model of the konak building in Travnik under Ottoman rule, with the traditional Bosnian steep roof silhouette, wooden roof-cover and hatches for the smoke (photo Jaeger-Klein, May 2019); Right: The building in 1950 with the gently-sloped roof, the fire-proof brick covering and chimneys according to the regulations of AustroHungarian administration (photo from Sujoldžić, Stari Vodovodi, 2012, p.94)

A set of plans, which survived and are located in Travnik Canton's district archive, give us some hints about this adaptation process. From 1882 to 1886, the existing building, including its steep traditional Bosnian roof structure, gained a new brick-tile covering. This was implemented in several phases. Additionally, a new heating system with fireproof chimneys was installed, maybe partially already under Ottoman rule. Noticeable in particular is the roof-plan, which details the replacement 
of the traditional wooden roof-cover by brick-tiles, as the contemporary black-and-white photo shows. Obviously, the government could not afford to change the cover into brick within one budgetyear. The plan gives evidence that it was done over four periods: 1882 first in dark red, and then from 1884 to 1886 once a year another part, and finally for the last phase, marked in very pale red, the figure of $177 \mathrm{~m} 2$ in total is given. Also visible are the new chimneys, which replaced the hatches for smoke.
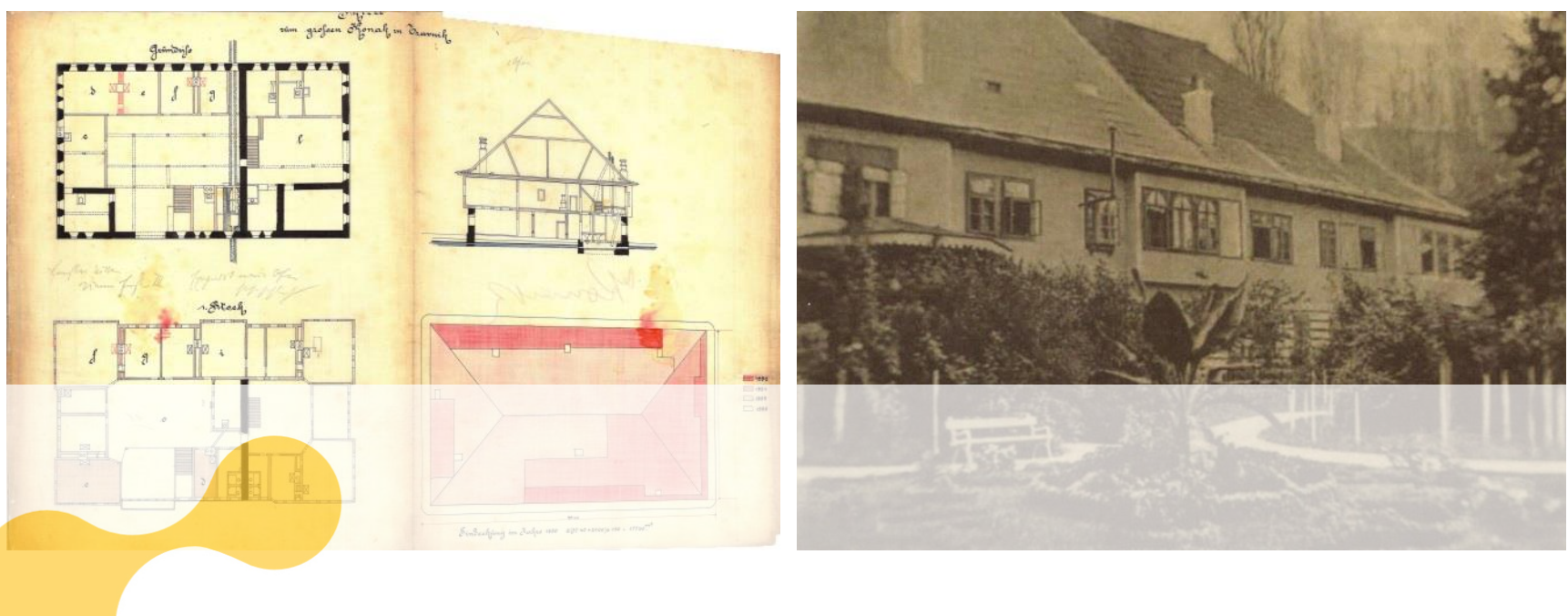

Figure 2: Left: The first adaptation phase (1882-86) of the 'great konak building' in Travnik under Austro-Hungarian rule; the roof-cover was switched to burnt brick material in four stages (scan from the district archive of the Travnik Can-
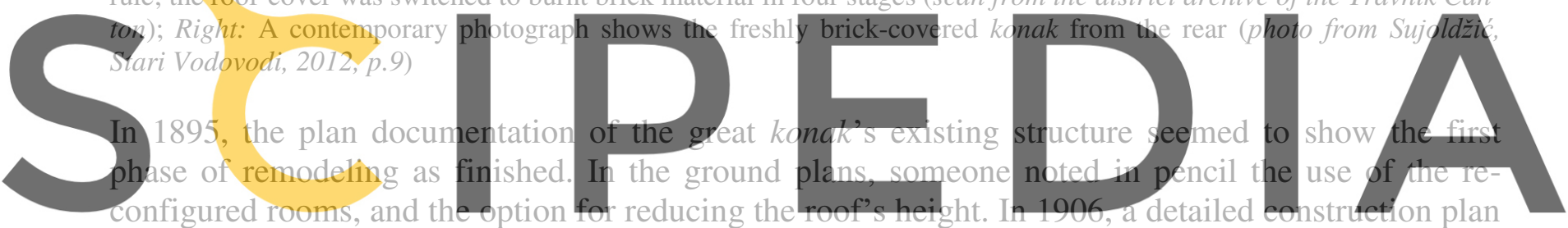

fixes this proposed height reduction and replacement of the traditional Ottoman-era roof-structure.



tion phase. This series of plans matches the reports by Stix (1887) and Schmid (1914), who testify

that during the new administration's early years existing structures were adapted to administrative purposes. For financial reasons, they were equipped according to the new building-code standards of Austro-Hungary, with minimal effort.
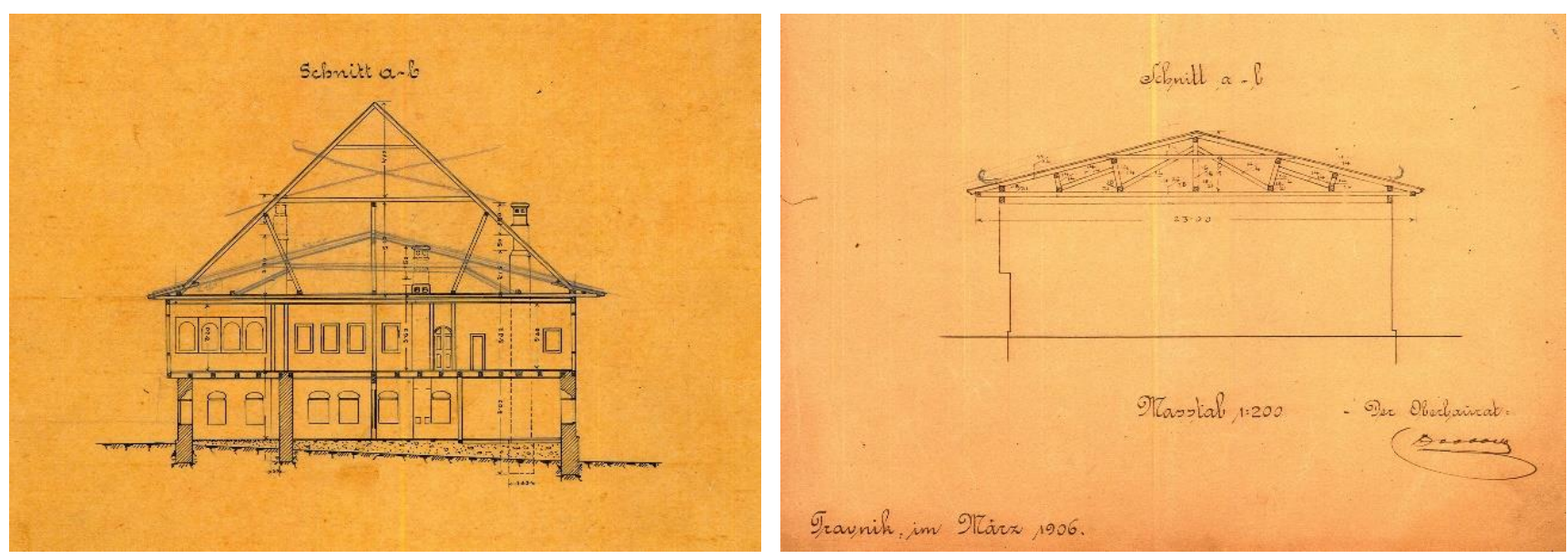

Figure 3: Some early considerations about the modified roof-structure, from the documentation plans of 1895 (left) and the final solution from March 1906 (right); both scans from the district archive of Travnik Canton 


\subsection{The great fire of Travnik in 1903}

In September 1903, Travnik suffered a major fire. It started on September 3 as a result of a large spark from a passing locomotive, igniting the hay in a building around the Hasanpašić Tower, in the Sumeće mahala, at the eastern end of town. A precise plan, drawn by Austro-Hungarian clerks immediately after the fire, shows in detail how the fire spread and was rapidly transmitted from one place to another due to strong winds. Firefighting teams consisting of volunteers from Jajce, Zenica and Sarajevo had little success in extinguishing the fire, mainly due to a lack of sufficient equipment but also due to the fast burning of densely packed wooden buildings. The wooden mosques, including the surrounding porches of wood and their wooden minarets directly attached to the steep-hipped roofs, burned particularly well. The different firefighting lines, which the authorities documented well in the mentioned plan, did not work well enough. Only the barrier of the railway managed to keep the fire out of the town's southern part.

There was, however, another fire, which started on September 10 of the same year. It spread across the railway tracks and into the central parts of town. According to the various reports, half of the population lost their homes and their income, since in addition to the 582 destroyed houses, 60 shops and warehouses as well as 337 commercial buildings were lost or heavily damaged. The AustroHungarian government reacted quickly by investing in the town's rebuilding. Building material like timber, stone and sand were provided for free and, as after the 1879 fire in Sarajevo, taxes for the newly built houses were exempted for ten years, for poorer citizens even twenty years [17].
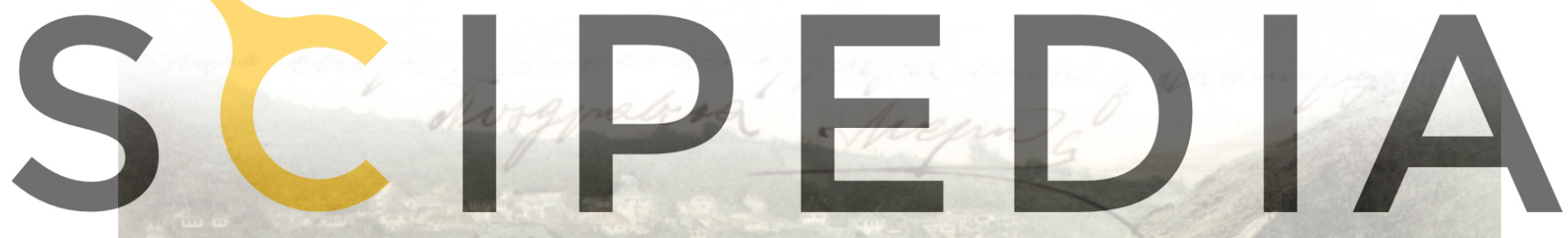

Register for free at https//www.scipedia.com to download the version without the watermark

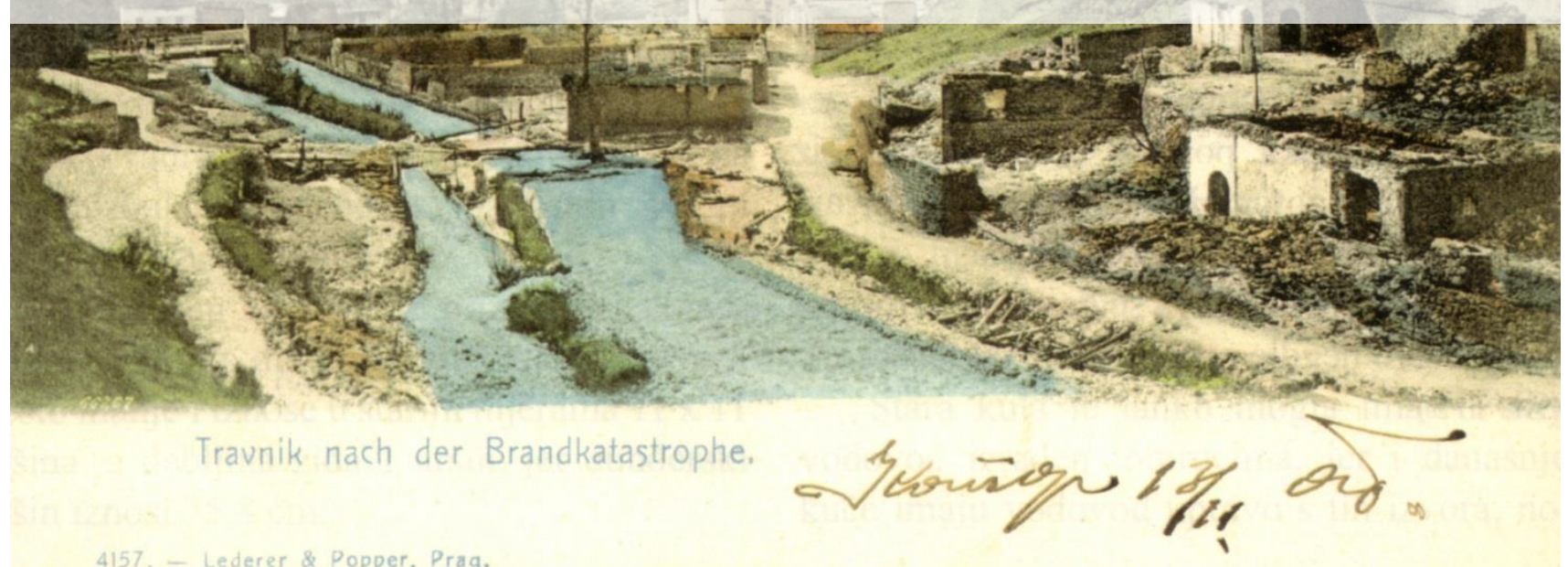

Figure 4: The results of the 1903 Travnik fires in a photograph (Source: Sujoldžić, Sjećanje, 2019, p.135) 


\subsection{The reconstruction of Travnik's mosques under Austro-Hungarian administration}

In the great fire of 1903 nine mosques were damaged. The state government (Landesregierung) supported the reconstruction of three mahale-mosques in the Šumećka, Kahvica and Zulići neighborhoods. Two other mosques of this type from the east end of town, Varoška and Lončarica, were rebuilt with private local donations. For Lukačka mosque, prominently located on the main street, the Austro-Hungarian governor Stephan Burián personally financed its reconstruction. At first glance, it is obvious that four mosques - Sumećka, Kahvica, Zulići and Lončarica - were built on the base of a fixed model. So far, the ERC research team could locate only one plan set in Bosnian archives, the blue-print of Kahvica mosque's design.



\section{Registergfor Freet: at and Hercegovina, GD2VS, 1878-1918, Box 646, obj 65), dated December 1907; Right: Section through a typical tradi- tional wooden mosque of Travnik (plan of Osoje mahale mosque from Sujoldžić, Džamije, 2013, p.111). Kahvica Miosque was one such typical wooden neighborhood mosque before the great fire of 1903 destroyed it.}

At the end of the nineteenth century, the Austro-Hungarian government of Bosnia had popularized an Orientalizing style through its architectural projects. This style mostly drew upon the Islamic artistic heritages of Andalusia and Egypt. The Kahvica mosque's blueprint reveals that the administration's architects, trained in the universities and academies of the monarchy, could design in the 'Oriental aesthetic'. To implement it constructively, they stayed within their Austrian-based knowledge and experience. Their Western training probably led to a smooth use of type planning, which could come in handy for situations like the one in Travnik after the great fire. For many building types, such as school-buildings, train stations and administrative structures, the central building administration of Sarajevo province seemed to have developed model-plans that district engineers could quickly modify according to local circumstances. The freshly rebuilt Lončarica, Zulići, Kahvica and Sumećka mosques seem to follow such a model-plan. A group of master-students from Vienna University of Technology went to Travnik in May 2019 to survey the mosques in situ. 

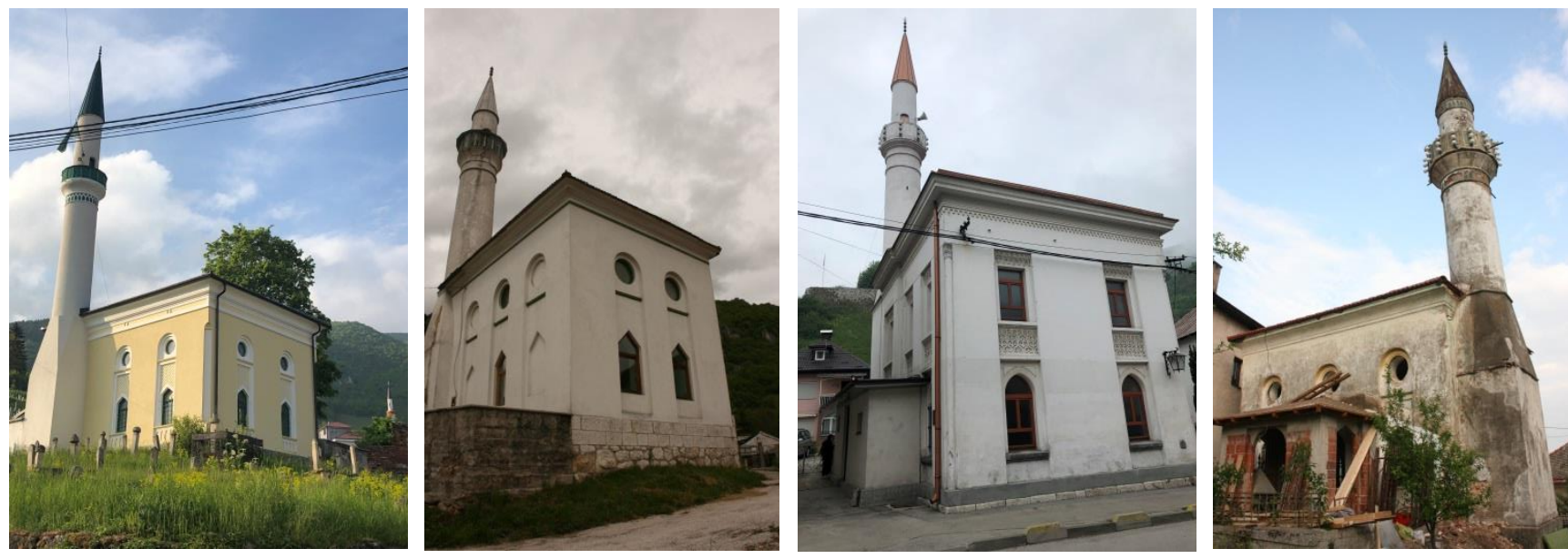

Figure 6: Mosques built according to one model-plan in Travnik after the great fire: From the left: Lončarica, Zulići, Šumećka and Kahvica (all photos by Jaeger-Klein in May 2019)

As preliminary results, the following can be stated: the footprint of the mosques and their size accords with the lost wooden mosques that they replaced. Their facades all follow a $3 \times 2$ module with two levels of windows, but variations in ornament. For those ornaments, the local Austro-Hungarian technicians developed a variation on motifs from the great representative structures like the Elči Ibrahim-paša medresa; that structure was built in the distinct Austro-Hungarian Orientalizing style in 1895 after designs by Cinit Iveković (1844-1933), one of the prestigious architects employed by the

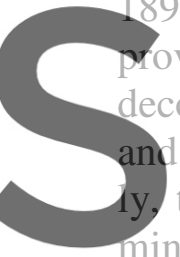

ovincial government

lecoration. Sitting at one

they now match the

ninarets. The steep, tenth
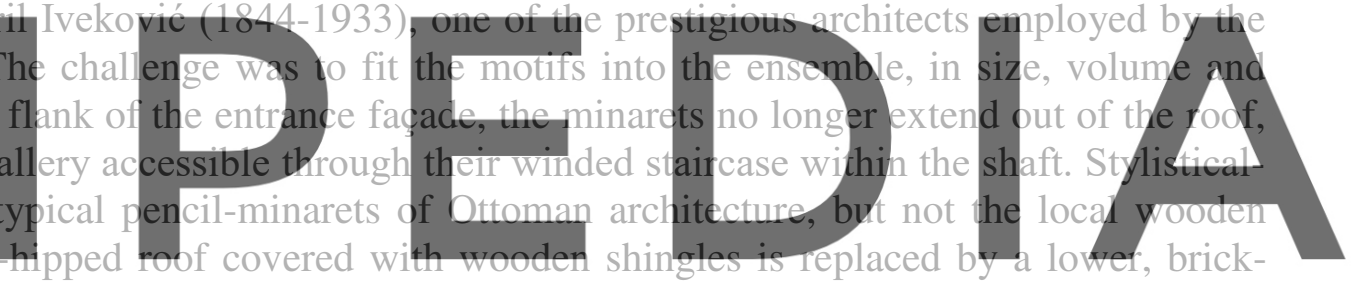

covered, but still tent-hipped roof. Finally, all the materials as well as the construction techniques



Two of the reconstructed mosques certainly do not follow this model and were individually planned. Varoška mosque, before the great fire of 1903 certainly a typical mahala-mosque constructed from cedar wood with a traditional Bosnian roof, was 'upgraded' to a mosque with a, for Bosnia, highly unusual onion-shaped cupola and extremely high minaret [18]. The reason for this upgrade is unknown. Maybe this is a tribute to the specific history of the Varoška mosque. It was Travnik's first mosque built in the suburb (Varoš) outside of the medieval castle's defense-walls. With the generous donation of a local lady, Ziba Hanuma Arnautović-Kopčić, the mosque was realized quickly in 1906, according to Sujoldžić after plans by the architect Miloš Milosević [19], who is not listed as one of the local Austro-Hungarian administration's technicians. Varoška mosque's new configuration clearly represents the Orientalizing style, which Austro-Hungary used as a kind of corporate identity. Distinct ochre-red horizontal stripes cover its façade. The entrance is marked by a monumentalized double-story porch, which reveals the Austro-Hungarian interpretation of in general oriental, but certainly not local elements of architecture.

The second mosque, the shape and aesthetic of which does not correspond to the four type-planned ones, is the Lukačka mosque. Located on the main-street of Travnik, this mosque needed only partial reconstruction after the second great fire of September 1903. The 1821 configuration of this early seventeenth-century mosque is described as a rectangular volume with a lower four-hipped roof and a porch of six stone pillars that reached to the height of the eves. 
Its walls already consisted of a massive structure, with a brick-tiled roof and a minaret made of stone, enabling the mosque to survive the conflagration. The Austro-Hungarian governor Stephan Burián, who visited Travnik after the fire, privately financed its necessary retrofitting [20]. The porch was lowered, and gained an Egyptian-Mameluke-inspired crenellation and extraordinarily slim columns. Their shafts were from cast-iron, while bases and heads were from gypsum-mortar in muqarnas-décor. The whole exterior was whitewashed, and some of the former colored, figurative murals survived in the roof-structure of the new porch [21].

This illustrates the wide spectrum within the Orientalizing style, reinterpreted by the AustroHungarian architects and engineers. Lukačka mosque did not use any color other than white for its facade. The materials used make for an interesting observation: apparently, all of the porch columns were made of industrially produced rounded iron-profiles, which could have been used for railway platform shelters. Other European architects working in the Near East, like Carl von Diebitsch (1819-1869), used to pre-order iron casts or pillars for their constructions in Orientalizing styles and assembled them in situ, which may explain why cast-iron columns were also used in Travnik.


Register for/free at https//www.scipedia.com to download the version without the watermark
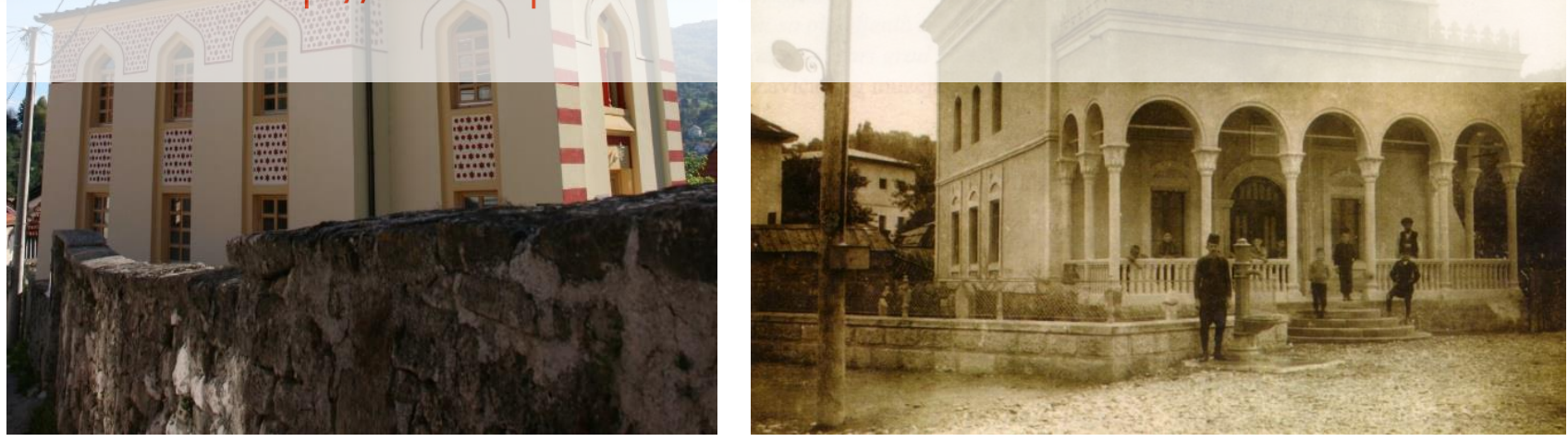

Figure 7: Reconstruction of mosques in the style promoted by the regional government: Left: Varoška mosque in Travnik: Monumentalized replacement of the former wooden, modest mosque (photo Jaeger-Klein, September 2018); Right: Lukačka mosque in Travnik with its new porch replacing the former double-floor height one (historic photo from Sujoldžić, Sjećanje, 2019, p.167) 


\section{MAINTAINING THE TRADITIONAL CITY SCAPE AFTER DESCTRUCTION}

The measures undertaken by the government to avoid fire tragedies of this scale were rather effective, if we consider that the Austro-Hungarian building stock remained pretty much intact into the twenty-first century. Nevertheless, contemporary critique arose quickly even under the AustroHungarian officials. Edmund Stix, head of the Bosnian building department in Sarajevo, stated critically in 1887 that the picturesque "oriental character" of the towns was already fading [22]. Even though the newly erected or renovated buildings followed the new building protocols, they lost authenticity. Later, in Travnik, the new buildings were not designed thoughtlessly. The mahalemosques, for example, kept their architectural footprint as well as their traditional scale. The big ko$n a k$ of the Ottoman viziers, which Austro-Hungarian technicians upgraded to their structural standards, stood in place until 1950, when it was demolished by the authorities with the goal of creating a new city center in the global language of Yugoslav architecture [23].

\section{CONCLUSIONS}

- When the Austro-Hungarian administration took over rule of Bosnia and Herzegovina, it already had long-term experience in fire-prevention from Vienna by means of building regulations and the rigid supervision of proper implementation.

- The disastrous Sarajevo fire in 1879 led the authorities to take immediate action by implementing a modern Building Code for Sarajevo and other selected Bosnian towns. They supervised especially its proper implementation, but encouraged citizens to rebuild quickly according to the new standards through means of tax relief and tax exemption.

- The 1903 fire-catastrophe in Travnik proved that buildings retrofitted according to modern regulations, like the renovated Ottoman konak, survived even such destructive events.

- $\quad$ Replacing the steep wooden roofs of traditional Bosnian architecture as well as rebuilding wooden mosques with fireproof material was an effective measure against fire disasters but it interfered heavily with the traditional cityscape.

- To counterbalance this loss of cultural identity, the new authorities promoted an Orientalizing style.

Acknowledgements. We would like to extend our sincere thanks to the director of the Local Museum Travnik, Mrs. Fatima Maslić and her team for their overwhelming support and assistance. Especially helpful were the talks we had with Mr. Enver Sujoldžić, a passionate researcher of the local architectural history. He measured and documented the majority of local mosques before and during the Bosnian war (1992-1995) and therefore preserved at least some reliable information on the buildings, which are lost to us today. Thanks to him, Mrs. Maslić, her team and the staff of the district archive of the Travnik Canton, a surprisingly intact legacy of the Austro-Hungarian administration came to our attention. Finally, our warm thanks additionally go to Mr. Salih Effendi Indžić and the team of the Travnik Medžlis, who gave us unlimited access to the mosques for conducting our research, even during Ramadan. 


\section{REFERENCES}

[1] Hartmuth, M., Amtssprache Maurisch? Zum Problem der Interpretation des orientalisierenden Baustils im habsburgischen Bosnien-Herzegowina. In: Bosnien-Herzegowina und ÖsterreichUngarn, 1878-1918: Annäherungen an eine Kolonie. Eds. Clemens Ruthner \& Tamara Scheer. Tübingen 2018, p.251-268.

[2] Hauptresultate der Volkszählung in Bosnien und der Hercegovina vom 22. April 1895, Sarajevo 1896, p.XCIV.

[3] Donia, R. J., Islam under the Double Eagle: The Muslims of Bosnia and the Hercegovina, 1878-1914, Boulder, New York (1981), p.11.

[4] Donia, R. J., Islam under the Double Eagle: The Muslims of Bosnia and the Hercegovina, 1878-1914, Boulder, New York (1981), p.14.

[5] Enzersdorfer, A., Gebäude versus Paragraf, unpublished diploma-thesis Vienna University of Technology (2018), p.13.

[6] Enzersdorfer, A., Gebäude versus Paragraf, unpublished diploma-thesis Vienna University of Technology (2018), p.17.

[7] Circulare der k.k. Landesregierung im Erzherzogthume Oesterreich unter der Enns. Wien 1829, reprint Vienna (1840), p.1.

[8] Bertram, C., Ottoman Sarajevo. The Urban History of Sarajevo in the Ottoman Period and Into the Period of the Dual Monarchy: http://www.friends-partners.org/bosnia/cb1.html.

[9] Prstojević, M., Forgotten Sarajevo, Wien (2010), p.67.

[10] Österreichische Nationalbibliothek, ALEX - Historische Rechts- und Gesetzestexte online, Sammlung der Gesetze und Verordnungen für Bosnien und Hercegovina 1878-1880, p.180-283: http://alex.onb.ac.at/tab_lbh.htm.

[11] Österreichische Nationalbibliothek, ALEX - Historische Rechts- und Gesetzestexte online, Sammlung der Gesetze und Verordnungen für Bosnien und Hercegovina, Bauordnung für die Landeshauptstadt Sarajevo 1893, p.410-435: http://alex.onb.ac.at/tab_lbh.htm.

[12] Schmid, F., Bosnien und die Herzegovina unter der Verwaltung Österreich-Ungarns, Leipzig (1914), p. 525.

[13] Stix, E., Das Bauwesen in Bosnien und der Hercegovina von Beginn der Occupation durch die österr.-ung. Monarchie bis in das Jahr 1887. Wien (1887), p.103.

[14] Österreichische Nationalbibliothek, ALEX - Historische Rechts- und Gesetzestexte online, Sammlung der Gesetze und Verordnungen für Bosnien und Hercegovina 1878-1880, p.271f..; http://alex.onb.ac.at/tab_lbh.htm.

[15] Schmid, F., Bosnien und die Herzegovina unter der Verwaltung Österreich-Ungarns, 1914 p.525f.

[16] Hodnik, Z., Maslić, F., Travnik Vezir Konaği Maketi, Travnik (2012), p.16.

[17] Sujoldžic, E., Sjećanje na Travnik, Travnik (2019), p.132-136.

[18] Sujoldžic, E., Džamije Travnika, Travnik (2013), p.17-19.

[19] Sujoldžic, E., Džamije Travnika, Travnik (2013), p.18.

[20] Sujoldžic, E., Džamije Travnika, Travnik (2013), p.48.

[21] Sujoldžic, E., Džamije Travnika, Travnik (2013), p.47-53.

[22] Stix, E., Das Bauwesen in Bosnien und der Hercegovina von Beginn der Occupation durch die österr.-ung. Monarchie bis in das Jahr 1887. Wien (1887), p.103.

[23] Sujoldžic, E., Sjećanje na Travnik, Travnik (2019), p.88. 